\title{
Tooth Regeneration: Turning Hopes into Realities
}

Kriti Garg${ }^{1}$, Silky Mehta², C. V. Sruthi Vyaasini ${ }^{3}$, Bhavika Sindhu $^{4}$, Sheenam Kansal5*, Roopali Sharma ${ }^{6}$

\begin{abstract}
Functional tooth regeneration has shown promising therapeutic strategy. Tooth regeneration is possible by combine use of adult stem cells, growth factors, and scaffold. In recent years, researchers have explored tooth regeneration. Significant effort has been made in recent decades to identify and characterize tooth stem cells and to unravel the developmental programs which these cells follow to generate a tooth.

Keywords: Endodontics, Necrotic, Regeneration, Stem cell

Asian Pac. J. Health Sci., (2020); DOI: 10.21276/apjhs.2020.7.3.8
\end{abstract}

\section{INTRODUCTION}

Since years, dentistry has been dealing with the replacement of missing teeth with the use of synthetic materials. ${ }^{[1]}$ Regenerative endodontic procedures have emerged as a viable, easy available alternative which allows root completion of immature teeth..$^{[2]}$ With this procedure, disadvantage of other methods can overcome easily (i.e., apexification and artificial apical barrier techniques) which do not allow the continuation of root development, leading to a fragile root structure and moreover vitality of the tooth cannot be restored. ${ }^{[3]}$ REPs work with the prerogative that the root canal space be free of contamination associated with a new stimulated blood supply can indeed reestablish vascularization, enhancing root completion. ${ }^{[2]}$

\section{Discussion}

Regenerative medicine holds promise for the restoration of tissues and organs and their vitality damaged by disease, trauma, cancer or congenital deformity. Regenerative medicine is defined as the use of a combination of cells, engineering materials ad suitable biochemical factors to improve or replace biological functions in an effort to effect the advancement of medicine. ${ }^{[4]}$

\section{Trilogy of Regeneration}

The regeneration of orodental tissues is dependent on appropriate signals, cells, blood supply and scaffold that are needed to target the tissue at the site of defect. For reconstruction and healing of lost tissues, all the components are essential. ${ }^{[5]}$

\section{Adult Stem Cells}

The most valuable cells for regenerative medicine are stem cells. All tissues originate from stem cells. A stem cell is commonly defined as a cell that has the ability to continuously divide and produce progeny cells that differentiate (develop) into various other types of cells or tissues. Stem cells can be divided into two categories embryonic and adult. ${ }^{[6]}$

Dental sources of adult stem cells are as follows:

- Dental pulp stem cells (DPSCs)

- Stem cells from human exfoliated deciduous teeth

- Dental follicle progenitor cells

- Stem cells from apical papilla

- Periodontal ligament stem cells. ${ }^{[6]}$
'Department of Conservative Dentistry and Endodontics, J.N. Kapoor DAV (C) Dental College, Yamuna Nagar, Haryana, India, 'Department of Paedodontics and Preventive Dentistry, J.N. Kapoor DAV (C) Dental College, Yamuna Nagar, Haryana, India, ${ }^{3}$ Department of Periodontics and Implantology, J.N. Kapoor DAV (C) Dental College, Yamuna Nagar, Haryana, India, ${ }^{4}$ Department of Paedodontics and Preventive Dentistry, Yamuna Institute of Dental Sciences, Gadholi, Yamuna Nagar, Haryana, India, ${ }^{5}$ Department of Conservative Dentistry and Endodontics, JCD Dental College, Sirsa, Haryana, India, ${ }^{6}$ Dental Surgeon, Yamuna Nagar, Haryana, India

Corresponding Author: Dr. Sheenam Kansal, Department of Conservative Dentistry and Endodontics, JCD Dental College, Sirsa, Haryana, India. Email: sheenamkansal@gmail.com

How to cite this article: Garg K, Mehta S, Vyaasini SVS, Sindhu B, Kansal S, Sharma R. Tooth Regeneration: Turning Hopes into Realities. Asian Pac. J. Health Sci., 2020; 7(3):30-34

Source of support: Nil

Conflicts of interest: None

Received: 30/04/2020 Revised:24/05/2020 Accepted:23/06/2020

\section{Scaffolds}

A scaffold provides the frameworkfor cell growth and differentiation at a local site. Ideally, a scaffold should be porous, biocompatible with the host tissues, should be in correct shape and form to allow for replacement of the lost tissues, and biodegradable. ${ }^{[7]}$ Two types of scaffolds are basically used: Natural and artificial.

Natural scaffolds offer good biocompatibility and bioactivity whereas synthetic scaffolds offer more control over the degradation rate and mechanical properties. ${ }^{[8]}$

\section{Growth Factors}

Growth factors are proteins that bind to receptors on the cell and induce cellular proliferation and/or differentiation. ${ }^{[9]}$ Many growth factors can be used to control stem cell activity such as by increasing the rate of proliferation, inducing differentiation of the cells into another tissue type, or stimulating stem cells to synthesize and secrete mineralized matrix. ${ }^{[10]}$

Regenerative endodontics must provide effective therapies for regenerating functioning pulp tissue and restoring lost dentinal structure to have a significant effect on clinical practice.

For example, dentin contains many proteins capable of stimulating tissue responses. Etchants, restorative materials and 
even caries lead to the release of growth factors resulting in demineralization of the dental tissues. Calcium hydroxide may result in extraction of growth factors from the dentin matrix. Once released, these growth factors may play key roles in signaling many of the events of tertiary dentinogenesis, a response of pulp-dentin repair. ${ }^{[11]}$ Different growth factors with their sources and activity are described in Table 1. ${ }^{[12,13]}$

\section{Technologies for regenerative endodontics}

There are several major areas of research that might have application in the development of regenerative endodontic techniques. These techniques are as follows:

Root canal revascularization through blood clotting, postnatal stem cell therapy, pulp implantation, scaffold implantation, injectable scaffold delivery, three-dimensional cell printing and gene delivery. ${ }^{[12]}$

\section{Root Canal Revascularization through Blood Clotting}

Several case reports have documented revascularization of necrotic canal by disinfection followed by establishing bleeding into the canal system via over-instrumentation. The use of intracanal irrigants ( $\mathrm{NaOCl}$ and chlorhexidine) with placement of antibiotics (e.g., a mixture of ciprofloxacin, metronidazole and minocycline paste) for several weeks is important part of procedure.

Disinfection of root canal followed by the formation of blood clot matrix that trap cells capable of new tissue formation, although it is not clear the regenerated tissue's phenotype resembles dental pulp; however, case reports published to date do demonstrate continued root formation and the restoration of a positive response to thermal pulp testing. ${ }^{[2]}$

\section{Advantages}

- Simple, cost effective, completed with currently available instruments and medicaments.

- Avoid immune rejection, pathogen transmission from replacing the pulp with a tissue engineered construct. ${ }^{[12]}$

\section{AAE Regenerative Endodontic Procedure ${ }^{[14]}$}

\section{First appointment}

- Local anesthesia, dental dam isolation and access.

- Copious, gentle irrigation with $20 \mathrm{~mL} \mathrm{NaOCl}$ with minimum extrusion of irrigants into the periapical space. About 1.5\% $\mathrm{NaOCl}$ is recommended followed by irrigation with saline, with irrigation needle positioned about $1 \mathrm{~mm}$ from root end, to minimize cytotoxicity to stem cells in the apical tissues.

- Dry canals with paper points.

- Calcium hydroxide or low concentration of triple antibiotic paste is placed.

If the triple antibiotic paste is used:

1. Sealing pulp chamber with dentin bonding agent.

2. Mix 1:1:1 ciprofloxacin:metronidazole:minocycline to final concentration of $0.1 \mathrm{mg} / \mathrm{mL}$.

- Deliver into canal system through syringe. TAP below cementenamel junction (CEJ).

- A 3-4 mm of a temporary material such as CavitTM, IRMTM, and glass ionomer are used for sealing.

\section{Second appointment (1-4 weeks after the first visit)}

- Assess response to initial treatment. If signs/symptoms of persistent infection, additional treatment with antimicrobial agent.

- $\quad$ About 3\% mepivacaine without vasoconstrictor administered as anesthesia, isolation with rubber dam, irrigation with $20 \mathrm{~mL}$ of $17 \%$ EDTA.

- $\quad$ Dry with paper points.

- $\quad$ Bleeding is induced by rotating a pre-curved K-file at $2 \mathrm{~mm}$ past the apical foramen with the goal of having the entire canal filled with blood to the level of CEJ.

- Stop bleeding at a level of CEJ that allows for 3-4 mm of restorative material.

- Place a resorbable matrix such as CollaPlug or other material over the blood clot if necessary and capping material such as white MTA/CaOH can be used.

Table 1: Source, activity and usefulness of common growth factors

\begin{tabular}{|c|c|c|c|c|}
\hline Abbreviation & Source & Factor & Activity & Use \\
\hline BMP & Bone matrix & $\begin{array}{l}\text { Bone } \\
\text { morphogenetic } \\
\text { protein }\end{array}$ & $\begin{array}{l}\text { Induces differentiation of osteoblasts } \\
\text { and mineralization of bone }\end{array}$ & $\begin{array}{l}\text { Make stem cells synthesize } \\
\text { and secrete mineral matrix }\end{array}$ \\
\hline CSF & Wide range of cells & $\begin{array}{l}\text { Colony-stimulating } \\
\text { factor }\end{array}$ & $\begin{array}{l}\text { Cytokines that stimulate the } \\
\text { proliferation of specific pluripotent } \\
\text { bone stem cells }\end{array}$ & $\begin{array}{l}\text { Used to increase number of } \\
\text { stem cells }\end{array}$ \\
\hline EGF & Submaxillary gland & $\begin{array}{l}\text { Epidermal growth } \\
\text { factor }\end{array}$ & $\begin{array}{l}\text { Promote proliferation of } \\
\text { mesenchymal, glial, and epithelial cells }\end{array}$ & Increase number of stem cells \\
\hline FGF & Wide range of cells & $\begin{array}{l}\text { Fibroblast growth } \\
\text { factor }\end{array}$ & Proliferation of cells & Increase stem cell numbers \\
\hline IGL & $\begin{array}{l}\text { I: Liver } \\
\text { II: Variety of cells }\end{array}$ & $\begin{array}{l}\text { Insulin growth } \\
\text { factor I OR II }\end{array}$ & Proliferation of many cells & Increase stem cell numbers \\
\hline IL & Leukocytes & $\begin{array}{l}\text { Interleukins IL-1 To } \\
\text { IL-13 }\end{array}$ & $\begin{array}{l}\text { Stimulate humoral and cellular } \\
\text { response }\end{array}$ & $\begin{array}{l}\text { Promote Inflammatory cell } \\
\text { activities }\end{array}$ \\
\hline PDGF & $\begin{array}{l}\text { Platelet endothelial cells and } \\
\text { placenta }\end{array}$ & $\begin{array}{l}\text { Platelet-derived } \\
\text { growth factor }\end{array}$ & $\begin{array}{l}\text { Proliferation of connective cells, glial } \\
\text { cells, and smooth muscle cell }\end{array}$ & Increase stem cell numbers \\
\hline TGF a & $\begin{array}{l}\text { Macrophages, brain cells, and } \\
\text { keratinocytes }\end{array}$ & $\begin{array}{l}\text { Transforming } \\
\text { growth factor alpha }\end{array}$ & Wound healing & $\begin{array}{l}\text { Induces epithelial and tissue } \\
\text { structural development }\end{array}$ \\
\hline TGF $\beta$ & $\begin{array}{l}\text { Dentin matrix activated, } T \\
\text { helper, and natural killer cells }\end{array}$ & $\begin{array}{l}\text { Transforming } \\
\text { growth factor beta }\end{array}$ & $\begin{array}{l}\text { Wound healing, inhibit macrophages } \\
\text { proliferation }\end{array}$ & Mineralization of pulp tissue \\
\hline
\end{tabular}


- $\quad$ GIC layer of 3-4 mm is flown gently over the capping material and light cured for $40 \mathrm{~s}$. MTA can cause tooth discoloration. MTA alternate should also be used in teeth with esthetic concern as it results in discoloration.

- Anterior and premolar teeth - Use of CollaTape/CollaPlug and restoration with $3 \mathrm{~mm}$ of resin-modified glass ionomer (RMGI) followed by bonding a filled composite to the beveled enamel margin.

- Consider use of CollaTape/CollaPlug and restoration with 3 mm of MTA followed by RMGI or alloy in molar teeth or teeth with porcelain fused to metal crown.

\section{Follow-up}

Clinical and radiographic examination:

- $\quad$ Absence of pain, soft-tissue swelling or sinus tract.

- Resolution of apical radiolucency.

- Increased width of root walls 12-24 months after treatment.

- Increased root length.

- Pulp vitality test.

A modification of the current clinical protocol was established to avoid crown discoloration. This novel approach seals the dentinal tubules of the chamber, thus avoiding any contact with triple antibiotic paste and the dentinal walls. ${ }^{[15]}$

\section{Considerations for Clinical Regenerative Endodontic Procedures}

At present, there is no single recommended protocol associated with successful clinical outcome till date. Common features of cases with successful clinical outcomes after REPs are:

1. Young patient (age and health status).

2. Apex size and immature apex.

3. Dentinal walls should be instrumented minimally.

4. Disinfection and placement of an intracanal medicament.

5. Creation of a blood clot or protein scaffold in canal.

6. Effective coronal seal. ${ }^{[16]}$

\section{Age and Health Status of Patient}

Revascularization procedure has been limited in patients with 8-16 years of age. The success depends on patient's ability to heal the dental pulp tissues. Not recommended in children younger than 8 years or older than 16 years, unless the tooth has an open apex with thin walls. ${ }^{[16]}$

\section{Apex Size and Stage of Tooth Maturity}

Traumatized immature permanent teeth with an apex that is open to a diameter of $1.1 \mathrm{~mm}$ or larger are the best candidates for regenerative endodontic procedures. Revascularization through an open apex allows the delivery of mesenchymal stem cells into the root canal space of necrotic immature teeth after a clinical regenerative endodontic procedure. This could allow host cell homing to form new tissues in the root canal space. ${ }^{[17]}$

\section{Minimal or No Instrumentation of the Dentinal Walls}

Root canal instrument not only increases fragility of dentin walls but also injures stem cells present in the apical area of these dentin walls and results in elimination of growth factors. ${ }^{[15]}$

\section{Disinfection Treatments}

\section{Irrigants and chelating agents}

If sodium hypochlorite is used in conjunction with regenerative endodontic treatments, it should be flushed from the root canals with saline in an attempt to reduce toxicity that reduces the regeneration responses. ${ }^{[18]}$

Disinfection with chlorhexidine was used due to its antimicrobial properties and low cytotoxicity. If both of these irrigants are used in the canal, it is prudent to irrigate with sterile water or saline between applications. ${ }^{[19]}$

\section{Hydrogen Peroxide}

Hydrogen peroxide is antiseptic by release of oxygen radical. However, it requires a rinse to reduce pain and possible postoperative gaseous emphysema. ${ }^{[20]}$

Chelating agents such as EDTA, citric acid and MTAD may also be used to remove the smear layer.

\section{Intracanal Medications}

Regeneration procedures use a triple antibiotic paste, sometimes called Hoshino's paste which contains 200 mg ciprofloxacin, 500 $\mathrm{mg}$ metronidazole and $100 \mathrm{mg}$ minocycline, manipulated in propylene glycol vehicle. Paste is inserted through Lentulo spiral drill, syringe, or manual files.

The triple antibiotic paste is placed in contact with the necrotic pulp inside the root canal for up to 1 month before the revascularization procedure.

Recently, calcium hydroxide has been tested with pulp revascularization, showing clinical and radiographic success. It allows increase in thickness of dentinal walls. $\mathrm{Ca}(\mathrm{OH})_{2}$ would increase the expression of some kind of kinases which indicates proliferation of stem cells from pulp and ligament. Therefore, it would not be cytotoxic for stem cells and would support their proliferation. ${ }^{[16]}$

\section{Creation of a Blood Clot or Protein Scaffold in Canal}

To create blood clot in the canal space, apical tissues should be lacerated just below the cement enamel junction. This can be performed with an endodontic explorer or file. If bleeding does not occur, explorer or file is dipped in 17\% EDTA to prevent coagulation of the blood. If bleeding still does not occur, it may be necessary to place more antimicrobial in the canal to achieve additional healing and granulation tissue. Alternatives to a blood clot include (platelet-rich plasma [PRP]) and autologous fibrin matrix. ${ }^{[16]}$

\section{Effective Coronal Seal}

Regenerative endodontic procedures evoke bleeding into the root canal, which delivers undifferentiated mesenchymal stem cells in the root canal space. The survival of cells and regeneration of tissues is sensitive to the conditions within the intracanal environment, which must be biocompatible to allow new tissue formation. The placement of restorative materials in contact with the pulp tissue, root canal blood clot, or regenerating tissues is not recommended. These materials are not biocompatible to exposed pulp tissues because they can cause cell death and pulpitis and allow bacterial leakage. ${ }^{[16]}$ Restorative materials should be used 
only after a thin protective liner of MTA or calcium hydroxide has been placed in contact with the coronal pulp tissue, root canal blood clot or regenerating tissues. ${ }^{[21]}$

\section{Uses of Regenerative Endodontic Therapy}

\section{Treatment of immature permanent teeth with necrotic pulps}

Since the introduction of regenerative endodontic therapy for immature permanent teeth with apical periodontitis by lwaya et al., regenerative endodontic therapy has become a treatment option for immature permanent teeth with necrotic pulps. Thickening of the canal walls and/or increased root length is considered to be the favorable outcomes of regenerative endodontic because they may strengthen the root and increase the root/crown ratio. Importantly, the vitality, immunity and sensibility of immature permanent teeth with necrotic pulps are restored after regenerative endodontic therapy. ${ }^{[22]}$

\section{Treatment of mature permanent teeth with necrotic pulps}

Thickening of the canal walls and/or continued root development does not occur in mature permanent teeth following regenerative endodontic therapy. However, apical closure can take place. Elimination of clinical symptoms and resolution of apical periodontitis is similar to traditional non-surgical root canal therapy. Therefore, regenerative endodontic therapy provides another treatment option for mature permanent teeth with necrotic pulp. ${ }^{[23]}$

\section{Treatment of teeth with persistent apical periodontitis after root canal therapy}

Endodontic surgery is usually indicated if non-surgical treatment is not feasible. The outcome of secondary root canal treatment is less favorable than that of primary root canal treatment because of several possibly complicated factors. Recently, regenerative endodontic therapy has also been used to manage teeth with persistent apical periodontitis after root canal therapy. ${ }^{[24]}$

Clinical symptoms are eliminated and resolution of apical periodontitis occurs. Interestingly, thickening of the canal walls and apical closure was demonstrated after regenerative endodontic therapy of teeth with persistent apical periodontitis after root canal treatment. ${ }^{[25]}$

\section{Treatment of traumatized teeth with external inflammatory root resorption, horizontal root fracture, and avulsed teeth}

Traumatized teeth with external inflammatory root resorption, horizontal root fracture and complete avulsion are traditionally managed with control of root canal infection using chemomechanical debridement and root canal filling. ${ }^{[26]}$ Recently, REPs are used to treat traumatized teeth with horizontal root fracture, external inflammatory root resorption, and complete avulsion.

For external inflammatory root resorption to take place, the protective layer of pre-cementum must be damaged, likely by trauma or inflammation, thus leading to exposure of the underlying dentin. ${ }^{[27]}$

In addition, the canal space has to contain infected necrotic pulp tissue. The toxic products from bacteria and tissue breakdown in the canal space diffuse through the dentinal tubules, communicating with the root surface denuded of cementum, and initiate the inflammatory reaction. ${ }^{[28]}$ Treatment of external inflammatory root resorption is usually carried out by complete chemomechanical debridement, long-term calcium hydroxide dressing and root canal filling. Calcium hydroxide would prevent osteoclast activity. Long-term calcium hydroxide dressing in the canal space of immature permanent teeth weakens the fragile thin root structure, thus increasing the likelihood of root fractures.

External inflammatory root resorption of immature permanent teeth and horizontal root fracture caused by trauma resulting in pulp necrosis get resolved by REPs achieving healing of the root fracture by hard tissue formation. ${ }^{[29]}$

Avulsed teeth are treated with immediate replantation followed by chemomechanical debridement, calcium hydroxide dressing and root canal filling if the pulps become necrotic. Recently, an avulsed permanent mature incisor with more than 8 h extraoral dry time was replanted into the alveolar socket after complete chemomechanical debridement of the canal space and enlargement of the apical foramen to 1.5-2 $\mathrm{mm}$. The tooth was then treated with regenerative endodontic therapy, using PRP instead of blood clot as a scaffold. At 12-month follow-up, the tooth showed resolution of apical periodontitis and arrest of internal and external inflammatory resorption. ${ }^{[30]}$

\section{Can Regenerative Endodontic Therapy be used for All Necrotic Teeth?}

In some necrotic teeth, regenerative endodontics may not be suitable, for example, in teeth requiring a post for adequate techniques and it may be challenging in some others (e.g., tooth with pulp stones or pulp calcifications). ${ }^{[31]}$ Retreatment in tooth with earlier failed treatment with regenerative endodontic procedures can be a challenge. The teeth treated with root canal filling may have a poorer survival rate than the teeth treated with regenerative procedures because of lack of defense mechanisms such as immunoinflammatory and sensory response.

\section{Challenges and Limitations}

Regenerative endodontics has encountered substantial challenges toward clinical translation.

1. Recent adoption by the American Dental Association of evoked pulp bleeding in immature permanent teeth is an important step for regenerative endodontics. However, majority of endodontic diseases cannot be treated by REPs. ${ }^{[32]}$

2. Simple recapitulation of cell therapy and tissue engineering has not led to clinical translation in regeneration endodontics. DPSCs may appear to be choice for dental pulp regeneration. However, DPSCs may not be available in a patient who is in need of pulp regeneration.

3. Transplantation of DPSCs will remain a scientific exercise, rather than a clinical reality, unless these issues (scientific, regulatory, and commercialization) are resolved. ${ }^{[33]}$

\section{Conclusion}

Regenerative endodontic has the potential for regenerating both pulp and dentin tissues and therefore may offer an 
alternative method to save teeth that may have compromised structural integrity. Several techniques have been described to accomplish endodontic regeneration. Endodontists will have to be dependent on tissue engineering therapies to regenerate pulp dentin tissue, to make REPs a success, the future development of regenerative endodontic procedures will require a comprehensive research program directed at each of these components and their application to the patients. It is believed that regenerative endodontics is an inevitable therapy, and they call for action from scientists, funding agencies, and the endodontic profession to pool resources to hasten its development. Millions of patients get benefited by REPs each year.

\section{References}

1. Sharma S, Jindal L, Kumar A, Gaurav K, Munshi R, Anukriti. Die and die materials: An overview. Acta Sci Dent Sci 2020;4:22-8.

2. Banchs F, Trope M. Revascularization of immature permanent teeth with apical periodontitis: New treatment protocol? J Endod 2004;30: 196-200.

3. Jindal L, Bhat N, Vyas D, Thakur K, Neha, Mehta S. Stem cells from human exfoliated deciduous teeth (SHED) turning useless into miracle: A review article. Acta Sci Dent Sci 2019;3:49-54.

4. American Association of Endodontists. Regenerative Endodontics Database. Chicago: American Association of Endodontists; 2003.

5. Gupta SS, Mahendra A. Gene therapy with growth factors for periodontal tissue engineering a review. J Med Oral Pathol Cirugia Bucal 2012;12:301-10.

6. Jindal L, Dua P, Mangla R, Gupta K, Vyas D, Bhat N. Stem cells the tiny procreators: A review article. Asian Pac J Health Sci 2019;6:118-23.

7. Prescott RS, Alsanes R, Fayad MI, Johnson BR, Wenckus CS. In vivo generation of dental pulp like tissue by using dental pulp stem cells, a collagen scaffold and dentin matrix protein 1 after subcutaneous transplantation in mice. J Endod 2008;34:421-6.

8. Kim NR, Lee DH, Chung PH, Yang HC. Distinct differentiation properties of human dental pulp cells on collagen, gelatin and chitosan scaffolds. Oral Surg Oral Med Oral Pathol Oral Radiol Endod 2009;108:94-100.

9. Bazley LA, Gullick WJ. The epidermal growth factor receptor family. Endocr Relat Cancer 2005;12 Suppl 1:S17-27.

10. Martin I, Padera RF, Novakovic VG, Freed LE. In vitro differentiation of chick embryo bone marrow stromal cells into cartilaginous and bone like tissues. J Orthop Res 1998;16:181-9.

11. Murray PE, Smith AJ. Saving pulps: A biological basis. An overview. Prim Dent Care 2002;9:21-6.

12. Murray PE, Godoy FG, Hargreaves KM. Regenerative endodontics: A review of current status and a call for action. J Endod 2007;33:377-90.

13. Stevens MM, Marini RP, Schaefer D, Aronson J, Langer R, Shastri VP. In vivo engineering of organs: The bone bioreactor. Proc Nat Acad Sci 2005;102:11450-5.

14. Hargreaves KM, Giesler T, Henry M, Wang Y. Regeneration potential of the young permanent tooth: What does the future hold? J Endod 2008;34:S51-6.

15. Shokouhinejad N, Alikhasi M, Bagheri P, Camilleri J. Prevention of coronal discoloration induced by regenerative endodontic treatment Clin Oral Investig 2018;22:1725-31.

16. Lin LM, Kahler B. A review of regenerative endodontics: Current protocols and future directions. J Istanbul Univ Fac Dent 2017;51 Suppl 1:S41-51.

17. Kim JY, Xin X, Moioli EK, Chung J, Lee CH, Chen M. Regeneration of dental pulp like tissue by chemotaxis induced cell homing. Tiisu Eng Part A 2010;16:3023-31.

18. Chen SC, Chueh LH, Hsiao CK, Wu HP, Chiang CP. First untoward events and reasons for tooth extraction after nonsurgical endodontic treatment in Taiwan. J Endod 2008;34:671-4.

19. Ade SJ, Lins FF, Nagata JY, Gomes BP, Zaia AA, Ferraz CC, et al. Pulp revascularization after root canal decontamination with calcium hydroxide and 2\% chlorhexidine gel. J Endod 2013;39:417-20.

20. Nagata JY, Gomes BP, Lima RT, Murakami LS, Faria FD, Campos GR, et al. Traumatized immature teeth treated with 2 protocols of pulp revascularization. J Endod 2014;40:606-12.

21. Iwaya $\mathrm{SI}$, Iwaka $\mathrm{M}$, Kubota $\mathrm{M}$. Revascularization of an immature permanent tooth with apical periodontitis and sinus tract. Dent Traumatol 2001;17:185-7.

22. Kontakiotis EG, Filippatos CG, Agrafioti A. Levels of evidence for the outcome of regenerative endodontic therapy. J Endod 2014;40:1045-53.

23. Saoud TM, Chen GM, Yen HM, Chen KL, Chen CA, Songtrakul K, et al. Treatment of mature permanent teeth with necrotic pulps and apical periodontitis using regenerative endodontic procedures: A case series. J Endod 2016;42:57-65.

24. Nevins AJ, Cymerman JJ. Revascularization of open apex teeth with apical periodontitis using a collagen-hydroxyapatite scaffold. J Endod 2015;41:966-73.

25. Saoud TM, Huang GT, Gibbs JL, Sigurdsson A, Lin LM. Management of teeth with persistent apical periodontitis after root canal using regenerative endodontic therapy. J Endod 2015;41:1743-8.

26. Anderson JO, Andreasen FM, Anderson J. Textbook and Color Atlas of Traumatic Injuries to the Teeth. $4^{\text {th }}$ ed. Chichester, UK: Wiley Blackwell; 2017.

27. Tronstad L. Root resorption etiology, terminology and clinical manifestations. Endod dent Traumatol 1998;4:241-52.

28. Trope M. Root resorption due to dental trauma. Endod Top 2002;1:79-100.

29. Santiago CN, Pinto SS, Sassone LM, Hirata RJ, Fidel SR. Revascularization technique for the treatment of external inflammatory root resorption: A report of 3 cases. J Endod 2015;41:1560-4.

30. Priya H, Tambakad PB, Naidu J. Pulp and periodontal regeneration of an avulsed permanent mature incisor using platelet rich plasma after delayed replantation. A 12 month clinical case study. J Endod 2016;42:66-71.

31. Bhat N, Anjum R, Bhardwaj N, Thakur K, Nandan H. Stones within the dental pulp: Clinical Correlations. Int J Sci Res 2020;9:1-2.

32. Kim GS, Zhou J, Ye L, Cho S, Suzuki T, Fu SY, et al. Regenerative endodontics: Barriers and strategies for clinical translation. Dent Clin North Am 2012;56:639-49.

33. Iohara $\mathrm{K}$, Zheng $\mathrm{L}$, Ito $\mathrm{M}$. Regeneration of dental pulp after pulpotomy by transplantaion of CD 31(-)/CD 146(-) side population cells from a canine tooth. Regen Med 2009;4:377-85. 